\title{
Reexpansion pulmonary edema in children
}

\author{
Edema pulmonar de reexpansão em crianças
}

Edema pulmonar de reexpansión en niños

\begin{abstract}
Antonio Lucas L. Rodrigues', Carlos Eduardo Lopes², Mariana Tresoldi das N. Romaneli ${ }^{3}$, Andrea de Melo A. Fraga Ricardo Mendes Pereira ${ }^{5}$, Antonia Teresinha Tresoldi ${ }^{6}$
\end{abstract}

\section{ABSTRACT}

Objective: To present a case of a patient with clinical and radiological features of reexpansion pulmonary edema, a rare and potentially fatal disease.

Case description: An 11-year-old boy presenting fever, clinical signs and radiological features of large pleural effusion initially treated as a parapneumonic process. Due to clinical deterioration he underwent tube thoracostomy, with evacuation of $3,000 \mathrm{~mL}$ of fluid; he shortly presented acute respiratory insufficiency and needed mechanical ventilation. He had an atypical evolution (extubated twice with no satisfactory response). Computerized tomography findings matched those of reexpansion edema. He recovered satisfactorily after intensive care, and pleural tuberculosis was diagnosed afterwards.

Comments: Despite its rareness in the pediatric population (only five case reports gathered), the knowledge of this pathology and its prevention is very important, due to high mortality rates. It is recommended, among other measures, slow evacuation of the pleural effusion, not removing more than $1,500 \mathrm{~mL}$ of fluid at once.

Key-words: pulmonary edema; pleural effusion; tuberculosis, pleural; adolescent.

\section{RESUMO}

Objetivo: Relatar caso de paciente com quadro clínico e radiológico de edema pulmonar de reexpansão, patologia rara e potencialmente fatal.

Descrição do caso: Menino de 11 anos com febre e quadro clínico-radiológico de derrame pleural volumoso, inicialmente tratado como parapneumônico. Após descompensação clínica, realizou-se drenagem torácica, com saída de $3.000 \mathrm{~mL}$ de líquido. Evoluiu rapidamente com insuficiência respiratória aguda, necessitando de ventilação mecânica. Teve duas extubações malsucedidas e, devido à evolução atípica, realizou-se tomografia computadorizada, cujos achados foram compatíveis com edema de reexpansão. Após suporte intensivo, evoluiu satisfatoriamente e, posteriormente, foi diagnosticado com tuberculose pleural.

Comentários: É importante o conhecimento da patologia, ainda que seja rara na população pediátrica (encontrados apenas cinco casos descritos), para prevenção, visto que a taxa de mortalidade é muito alta. Recomenda-se, entre outras medidas, que o esvaziamento de um derrame pleural seja lento e que o volume total retirado não ultrapasse $1.500 \mathrm{~mL}$.

Palavras-chave: edema pulmonar; derrame pleural; tuberculose pleural; adolescente.

\footnotetext{
Instituição: Faculdade de Ciências Médicas da Universidade Estadual de Campinas (Unicamp), Campinas, SP, Brasil

'Médico-residente em Pediatria do Departamento de Pediatria da Faculdade de Ciências Médicas da Unicamp, Campinas, SP, Brasil

${ }^{2}$ Chefe da UTI Pediátrica do Hospital de Clínicas da Faculdade de Ciências Médicas da Unicamp, Campinas, SP, Brasil

${ }^{3}$ Mestre em Ciências pela Unicamp; Médica-Assistente do Departamento de Pediatria da Faculdade de Ciências Médicas da Unicamp, Campinas, SP, Brasil

${ }^{4}$ Doutora em Ciências pela Unicamp; Médica-Assistente do Departamento de Pediatria da Faculdade de Ciências Médicas da Unicamp, Campinas, SP, Brasil

${ }^{5}$ Doutor em Ciências pela Unicamp; Professor-Assistente do Departamento de Pediatria da Faculdade de Ciências Médicas da Unicamp, Campinas, SP, Brasil

${ }^{6}$ Livre-docente em Pediatria pela Unicamp; Professora-Associada do Departamento de Pediatria da Faculdade de Ciências Médicas da Unicamp, Campinas, SP, Brasil
}

\author{
Endereço para correspondência: \\ Antonio Lucas L. Rodrigues \\ Rua Roxo Moreira, 1.724, apto 11 - Cidade Universitária \\ CEP 13083-592 - Campinas/SP \\ E-mail: antoniollrodrigues@yahoo.com.br \\ Conflito de interesse: nada a declarar
}

Recebido em: 7/2/2013

Aprovado em: 24/3/2013 


\section{RESUMEN}

Objetivo: Relatar caso de paciente con cuadro clínico y radiológico de edema pulmonar de reexpansión, patología rara y potencialmente fatal.

Descripción del caso: Niño de 11 años con fiebre y cuadro clínico-radiológico de derrame pleural voluminoso, inicialmente tratado como parapneumónico. Después de la compensación clínica, se realizó drenaje torácico, con salida de 3000mL de líquido. Evolucionó rápidamente con insuficiencia respiratoria aguda, necesitando ventilación mecánica. Tuvo dos extubaciones mal sucedidas y, debido a la evolución atípica, se realizó tomografía computadorizada, cuyos hallazgos fueron compatibles con edema de reexpansión. Después de soporte intensivo, evolucionó satisfactoriamente y, posteriormente, se diagnosticó tuberculosis pleural.

Comentarios: Es importante el conocimiento de la patología, aunque sea rara en la población pediátrica (encontrados solamente cinco casos descriptos), para prevención, una vez que la tasa de mortalidad es muy alta. Se recomienda, entre otras medidas, que el vaciamiento de un derrame pleural sea lento y que el volumen total retirado no sobrepase $1500 \mathrm{~mL}$.

Palabras clave: edema pulmonar; derrame pleural; tuberculosis pleural; adolescente.

\section{Introduction}

Reexpansion pulmonary edema (RPE) is a rare and potentially fatal clinical entity. It usually occurs when a chronically collapsed lung is rapidly reexpanded after the evacuation of large amounts of fluid or air from the pleural space, often using high negative intrapleural pressures ${ }^{(1-5)}$.

This study reported the case of a child with large pleural effusion who developed severe RPE after tube thoracostomy, besides performing a review of the literature on the topic.

\section{Case report}

An 11-year-old Caucasian male patient with a history of fever, adynamia, myalgia, and chest pain for three days. Previous intermittent asthma. Physical examination: good general health status, febrile, respiratory rate of 23 breaths per minute, with no respiratory distress; pulmonary workup with vesicular breath sounds on the right side and abolished breath sounds on the left side, with dullness on percussion. No other relevant clinical findings. Chest radiograph on admission reveled homogeneous opacity on the left side, with obliteration of costophrenic and cardiophrenic sinuses on the left side (Figure 1). An ultrasound scan was performed, which revealed fluid up
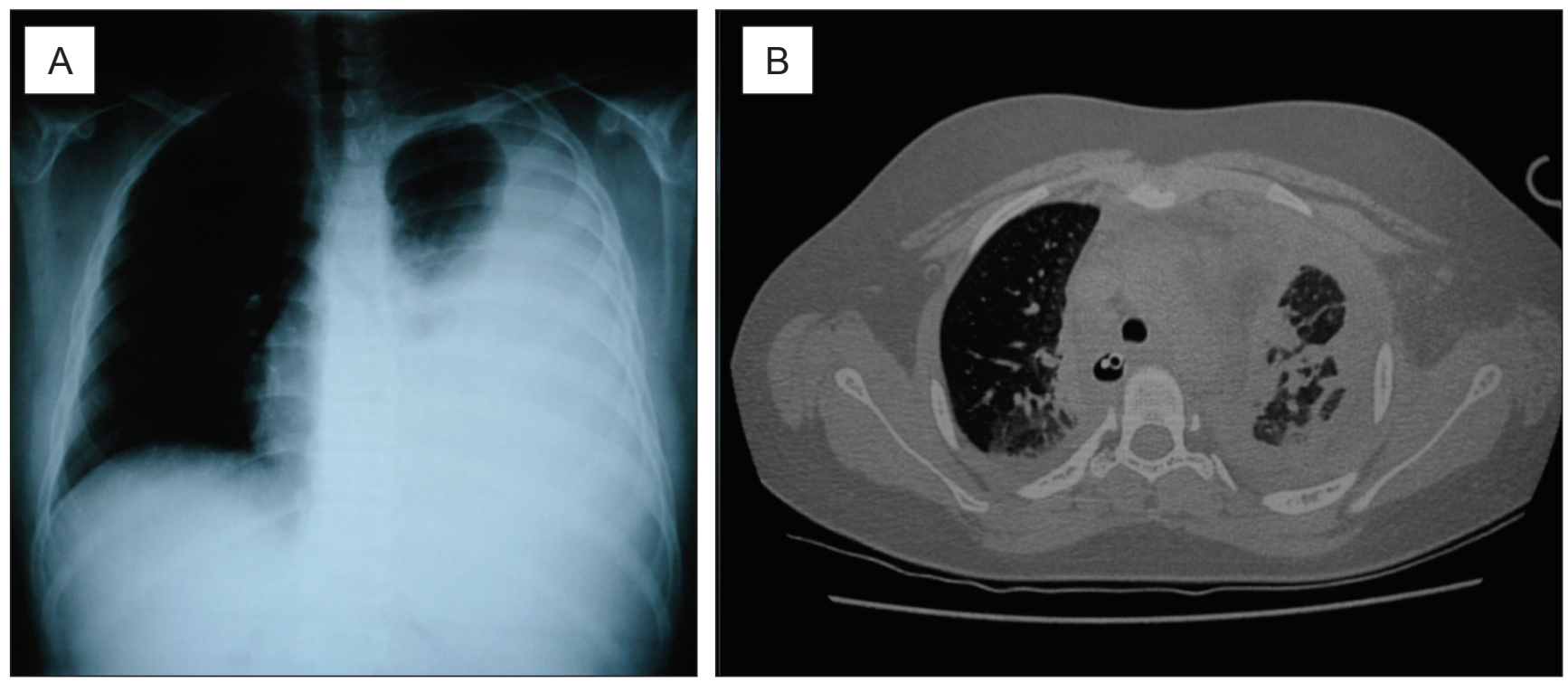

Figure 1 - (A) Chest radiograph on admission homogenous opacity on the left side up to the apex, opacification of costophrenic and cardiophrenic sinuses, with the presence of mild deviation of the contralateral mediastinum. (B) Chest computerized tomography after tube thoracostomy: axial cut, windowing for lung parenchyma evidencing bilateral lung involvement, with areas of condensation (alveolar filling), ground-glass areas and bilateral pleural involvement, with the left lung showing the most important findings 
to the upper third of the pleural cavity, with no septations or pleural thickening.

The patient underwent thoracocentesis, removing $550 \mathrm{~mL}$ of citrine fluid; blood count showed - hemoglobin: $14.2 \mathrm{mg} / \mathrm{dL}$; leukocytes: $7,310 / \mathrm{mm}^{3}$ (73\% segmented, $18 \%$ lymphocytes and $9 \%$ monocytes); platelets: $445,000 / \mathrm{mm}^{3}$. Treatment for parapneumonic pleural effusion was started with crystalline penicillin $(200,000 \mathrm{U} / \mathrm{kg} /$ day $)$. Laboratory analysis of the pleural fluid revealed: 4,400 erythrocytes $/ \mathrm{mm}^{3}$; 730 leukocytes $/ \mathrm{mm}^{3}$ (81\% lymphocytes and $19 \%$ neutrophils); glucose: $79 \mathrm{mg} / \mathrm{dL}$; proteins: $5.1 \mathrm{~g} / \mathrm{dL}$.

He remained in good general health status, eupneic, and with daily fever peaks for five days. Blood cultures, the rapid test for dengue and investigation for cold agglutinins were negative. Due to clinical worsening (chest pain and dyspnea), with no new radiological changes, pleural drainage under general anesthesia was indicated.

During anesthetic induction, he developed bradycardia and hypoxia, which were promptly reversed. Thoracocentesis was performed, with the evacuation of $3000 \mathrm{~mL}$ of citrine fluid during two hours, maintained by water-seal drainage. Fluid laboratory analysis: citrine appearance; 490 erythrocytes $/ \mathrm{mm}^{3} ; 233$ leukocytes $/ \mathrm{mm}^{3}$ (97\% lymphocytes); glucose: $94 \mathrm{mg} / \mathrm{dL}$; proteins: $4.2 \mathrm{~g} / \mathrm{dL} ; \mathrm{pH}$ : 7.48 ; lactate dehydrogenase (LDH): 623U/L (reference: exudate $>300 \mathrm{U} / \mathrm{L}$ ).

After the procedure, when he was already extubated, the patient developed respiratory distress and decreased oxygen saturation, needing invasive ventilation in the pediatric intensive care unit. He remained on mechanical ventilation from the sixth to the $20^{\text {th }}$ day of hospitalization. Within this 14-day post-procedural period, there were two extubations: one accidental and other planned; in both episodes, he needed to be intubated again, resuming mechanical ventilation due to respiratory insufficiency. During the periods when the patient was stable, it was decided to use intermittent mandatory ventilation, with peak inspiratory pressure between $20-25 \mathrm{cmH}_{2} \mathrm{O}$, positive-end expiratory pressure between $5-8 \mathrm{cmH}_{2} \mathrm{O}$, respiratory rate between $12-15$ breaths/minute and inspired oxygen concentration between $40-50 \%$ (the Horovitz index was calculated to be between 180-190). There was considerable difficulty in the evolution of ventilatory parameters until tracheal cannula was definitely withdrawn.

Chest computerized tomography was carried out (Figure 1), which evidenced: massive alveolar filling of the left lung and partial filling of the right lung, with bilateral areas of ground-glass opacity; residual pleural effusion on the left side and laminar effusion on the right side, with bilateral pleural reaction and presence of hilar adenomegaly. Thus, the diagnostic hypothesis was reexpansion pulmonary edema.

Complementary analysis of the pleural fluid showed negative results for investigations for neoplastic cells, fungi and bacteria; however, the investigation for adenosine deaminase (ADA) activity in the pleural fluid was positive (137.70U/L; reference: up to 40U/L). A tuberculin skin test was performed, with a result of $19 \mathrm{~mm}$. Treatment was started with rifampicin, isoniazid, pirazinamid and ethambutol, associated with prednisone $(1 \mathrm{mg} / \mathrm{kg} / \mathrm{day})$, with the diagnosis of pleural tuberculosis. Serology for HIV and cultures for bacteria and mycobacteria were negative. From the second day of treatment on, the patient had no febrile peaks anymore and could be weaned from mechanical ventilation; additionally, the pleural drain could be removed, at the $14^{\text {th }}$ of intensive care $\left(20^{\text {th }}\right.$ day of hospitalization). The patient was discharged for outpatient follow-up on the $31^{\text {rd }}$ day of hospitalization, with clinical and radiological improvement.

\section{Discussion}

The pathophysiology of RPE is multifactorial, including changes in pulmonary capillary permeability and increase in hydrostatic pressure. Both of them cause fluid and protein overflow into the pulmonary interstitial space and alveoli, leading to pulmonary edema ${ }^{(1-3,5)}$. Permeability changes occurs due to local hypoxemia, caused by lung collapse, injuring the capillary wall and decreasing surfactant production, with subsequent release of inflammatory mediators - interleukin-8 (IL-8), monocyte chemotactic protein-1 (MCP-1), leukotriene B4, nitric oxide, polymorphonuclear and free radicals- which, in turn, amplify the injury and change vascular permeability (IL- 8 and MCP- 1 act also in the contralateral lung, partly justifying the cases of bilateral RPE $)^{(2,3,5)}$. Besides this aggression, the capillary also undergoes mechanical injury by collapse compression, associated with sudden reexpansion-induced distension. In turn, the increase in hydrostatic pressure occurs due to the abrupt increase in blood flow on reinflation ${ }^{(2,3)}$. In the case reported herein, lung aggression was probably caused by the large cavitary effusion, associated with the increase in intraluminal pressure resulting from the reexpansion of the organ due to the evacuation of a great amount of pleural fluid.

The epidemiology of RPE is not well known yet. Reviews on the topic cover around a hundred cases up to the end of the 
twentieth century ${ }^{(1,2)}$. It is estimated that its incidence is up to $1 \%$ after drainage of intrapleural air or fluid ${ }^{(6)}$. However, most reports involve adult patients and there are no reviews of published pediatric cases ${ }^{(7)}$. The case reports of children with RPE are summarized in Table $1^{(7-11)}$.

Risk factors associated with RPE include: chronicity of lung collapse (usually greater than 72 hours); great amount of pleural air or fluid $(>1500 \mathrm{~mL})^{(1-3,5)}$; high speed of reexpansion and use of high negative pressures to do $\mathrm{so}^{(2,5)}$; hypertension, hypoxemia or other previous lung disease; pre-existing heart disease $e^{(2)}$; and male gender ${ }^{(3)}$. In the case described herein, the patient presented with chronic lung collapse (at least seven days of admission before drainage plus some period prior to hospitalization, considering a possible insidious onset of pleural tuberculosis); great intrapleural volume $(3000 \mathrm{~mL})$; lung disease (intermittent asthma); and male gender.

Clinical findings are variable, ranging from asymptomatic patients or presenting only non-specific symptoms (fever, nausea, vomiting, tachycardia, hypotension) to patients with severe respiratory insufficiency (dyspnea, chest pain, cough, foamy sputum, cyanosis) $)^{(2,3,5)}$. A simple chest radiograph may reveal interstitial opacities, consolidations with air bronchograms, and fissural inflammation ${ }^{(2)}$. Chest computerized tomography may show ground-glass opacity, residual pleural effusion, atelectasis, interlobar septum thickening, consolidations, air bronchograms, and pulmonary nodules. Nearly half of patients show diffuse involvement of the previously collapsed lung ${ }^{(4)}$ and bilateral pulmonary involvement is rarely observed ${ }^{(1,4,5,7,10)}$. The clinical picture of the patient described herein included respiratory insufficiency and need for mechanical ventilation with high parameters, similarly to some of the reported cases of children with RPE. However, computerized tomography findings as evident as those found by Gleeson $e t$ al ${ }^{(4)}$ in adults had not been described yet in pediatric patients.

Table 1 - Summary of reexpansion pulmonary edema cases in the pediatric population

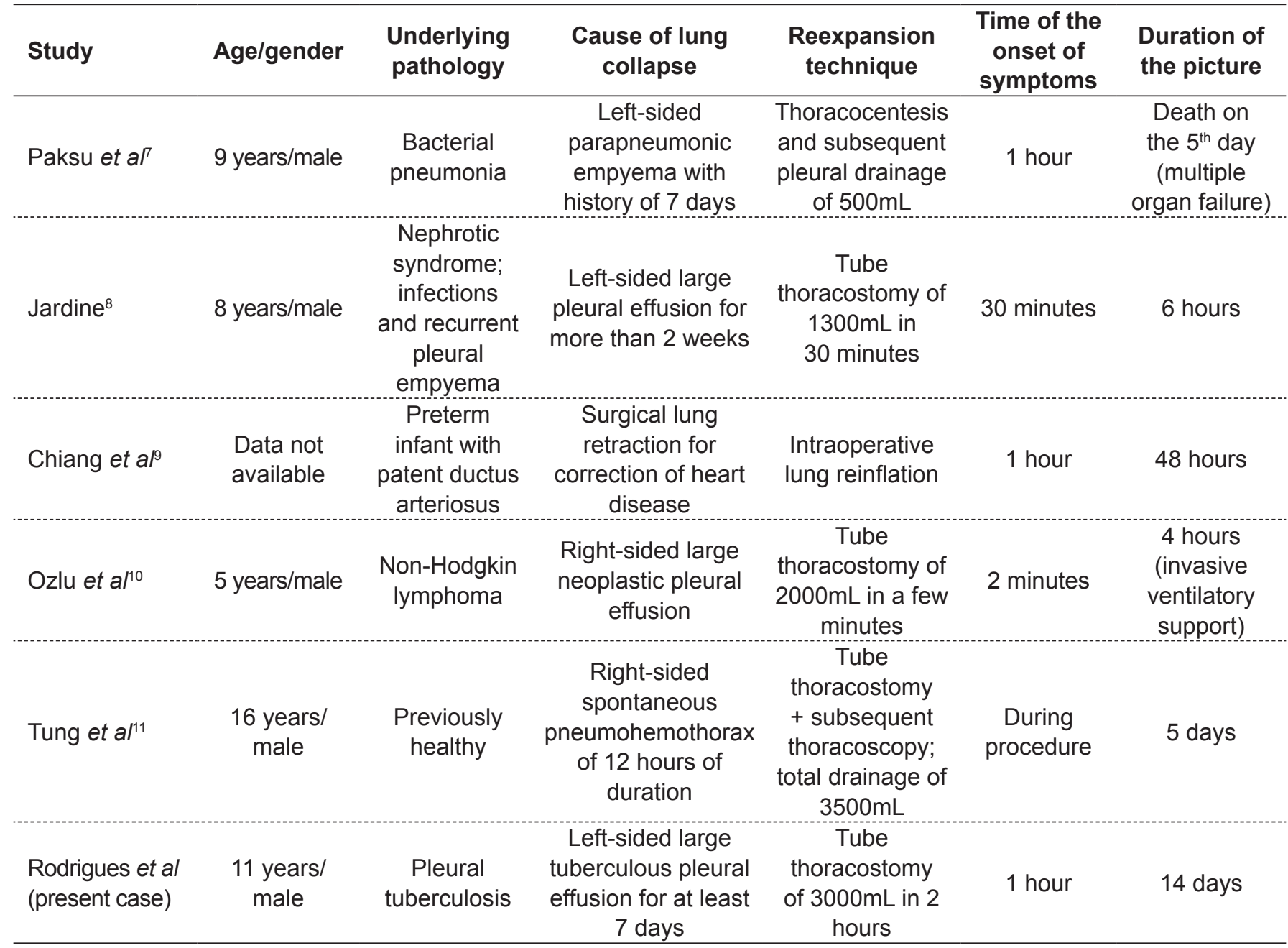


The onset of RPE symptoms usually occurs in the first 24 hours after pulmonary reexpansion, most frequently (64$89 \%)$ in the first two hours ${ }^{(3,5)}$. The duration of symptoms varies from 48 hours to seven days ${ }^{(2,8,10)}$, and mortality from 19 to $21 \%(2,3,5)$. In the case reported herein, the symptoms started in the first hour after the procedure and the duration of the clinical signs was 14 days, with the need for mechanical ventilation, probably due to complications during disease evolution (including unsuccessful extubations and extensive bilateral lung injury).

The treatment of this edema is based on clinical support according to the need of each patient ${ }^{(2,3,5)}$. Some authors suggest that the use of corticosteroids as stabilizers of the pulmonary vascular membrane ${ }^{(3,11)}$. More invasive measures are also described, such as occlusion of the pulmonary artery of the affected side ${ }^{(2)}$ and use of extracorporeal membrane oxygenation ${ }^{(11)}$. In the case reported herein, it was necessary to use invasive ventilatory support for 14 days, as well as the use of dobutamine (for four days; maximum titration of $0.45 \mathrm{mcg} / \mathrm{kg} / \mathrm{day}$ ), (furosemide for 14 days, for stimulation of diuresis and control of the water balance) e corticosteroid (although its exact role in the case could not be defined).

The diagnosis of pleural tuberculosis in the case described herein was based on clinical data (pleural effusion in febrile non-toxemic child/adolescent $)^{(12,13)}$, suggestive radiological finding (hilar adenomegaly) ${ }^{(13)}$ and positive skin tuberculin test ${ }^{(12)}$ (reaching 45 points in the scoring system proposed by the Brazilian Ministry of Health for children and adolescents, making this diagnosis highly likely) ${ }^{(14)}$. In addition, the analysis of the pleural fluid was

\section{References}

1. Mahfood S, Hix WR, Aaron BL, Blaes P, Watson DC. Reexpansion pulmonary edema. Ann Thorac Surg 1988;45:340-5.

2. Genofre EH, Vargas FS, Teixeira LR, Vaz MA, Marchi E. Reexpansion pulmonary edema. J Pneumol 2003;29:101-6.

3. Sohara Y. Reexpansion pulmonary edema. Ann Thorac Cardiovasc Surg 2008;14:205-9.

4. Gleeson T, Thiessen R, Müller N. Reexpansion pulmonary edema: computed tomography findings in 22 patients. J Thorac Imaging 2011;26:36-41.

5. Kesieme EB, Dongo A, Ezemba N, Irekpita E, Jebbin N, Kesieme C. Tube thoracostomy: complications and its management. Pulm Med [serial on the Internet]. 2012;2012 [cited 2012 Feb 20]. Available from: http://www.hindawi. com/journals/pm/2012/256878/cta/

6. Echevarria C, Twomey D, Dunning J, Chanda B. Does re-expansion pulmonary oedema exist? Interact Cardiovasc Thorac Surg 2008;7:485-9.

7. Paksu MS, Paksu S, Akgün M, Kalayci AG, Baysal K. Bilateral reexpansion pulmonary edema associated with pleural empyema: a case report. Eur J Pediatr 2011;170:1205-7.

8. Jardine DS. Reexpansion pulmonary edema. Am J Dis Child 1991;145:1092-4. characteristic: predominance of lymphocytes; high LDH levels; high ADA levels associated with lymphocyte-toneutrophils ratio $>75 \%^{(12,15)}$. Although the culture for mycobacteria in the fluid was negative, it is known that its positivity is low (45-55\% of the cases) ${ }^{(13,15)}$. If thoracoscopy with pleural biopsy was performed, positivity could be higher, as described in the literature ${ }^{(12)}$.

Predicting RPE occurrence is of fundamental importance in patients at risk for developing this condition and was even the subject of recommendations of the British Thoracic Society ${ }^{(6)}$. The evacuation of pleural effusion should occur slowly, not removing an excessive amount (up to $1500 \mathrm{~mL}$ ), and there should be available means to obtain a definitive airway and start mechanical ventilation if necessary ${ }^{(2,3,5,6)}$. It is also recommended that drainage is performed preferably with pleural pressure monitoring, not exceeding $-20 \mathrm{mmHg}^{(2,6)}$. In the case reported herein, the procedure was carried out in an operating room, with general anesthesia, by an experienced team, with equipment for emergencies available. However, it should be pointed out that the procedure could have had a different outcome if the amount of pleural fluid drained was lower or if the measure of cavity pressure was available on that occasion, considering that the patient had more than one risk factor for the development of RPE.

Therefore, despite its low frequency, RPE should be remembered as a potential complication in the evolution of a pediatric patient with large pleural effusion, particularly if there were other risk factors for the development of this complication.

9. Chiang MC, Lin WS, Lien R, Chou YH. Reexpansion pulmonary edema following patent ductus arteriosus ligation in a preterm infant. J Perinat Med 2004;32:365-7.

10. Ozlu O, Kiliç A, Cengizlier R. Bilateral re-expansion pulmonary edema in a child: a reminder. Acta Anaesthesiol Scand 2000;44:884-5.

11. Tung YW, Lin F, Yang MS, Wu CW, Cheung KS. Bilateral developing reexpansion pulmonary edema treated with extracorporeal membrane oxygenation. Ann Thorac Surg 2010;89:1268-71.

12. Fischer GB, Andrade CF, Lima JB. Pleural tuberculosis in children. Paediatr Respir Rev 2011;12:27-30.

13. Cruz AT, Ong LT, Starke JR. Childhood pleural tuberculosis: a review of 45 cases. Pediatr Infect Dis J 2009;28:981-4.

14. Conde MB, Melo FA, Marques AM, Cardoso NC, Pinheiro VG, Dalcin PT et al. III Diretrizes para tuberculose da Sociedade Brasileira de Pneumologia e Tisiologia. J Bras Pneumol 2009;35:1018-48.

15. Krenke R, Korczyński P. Use of pleural fluid levels of adenosine deaminase and interferon gamma in the diagnosis of tuberculous pleuritis. Curr Opin Pulm Med 2010;16:367-75. 